\title{
Molecular genetics in Streptococcus thermophilus: from transformation to gene expression
}

\author{
B Mollet, A Constable, M Delley, J Knol, O Marciset, D Pridmore
}

Nestlé Research Center, Nestlé Ltd, Vers-chez-les-Blanc, PO Box 44, 1000 Lausanne 26, Switzerland

\begin{abstract}
Summary - Streptococcus salivarius subsp thermophilus (S thermophilus) is a homofermentative, thermophilic lactic acid bacteria, used in dairy starter cultures. Despite its widespread and long-term use, its molecular biology and genetics have only recently started to be investigated. We report here the isolation and characterization of a cryptic, 3-kb plasmid which was converted into an $E$ coli $S$ thermophilus shuttle vector. Using this and other plasmids, transformation was optimized and used to integrate non-replicative plasmids into the bacterial genome. Resulting cointegrates were able to amplify. Resolution of the cointegrates was used for gene-replacement by introducing an in vitro generated deletion into a genomic located structural gene. By the same mechanism, a heterologous, promoter-less marker gene was inserted onto the genome between the permease and $\beta$ galactosidase gene of the lactose operon. It was thereafter expressed as a functional part of the operon and followed lactose regulation. The control region of the lactose operon was investigated by analyzing promoter up and down mutants.
\end{abstract}

Streptococcus salivarius subsp thermophilus / molecular genetics / transformation / genomic integration / gene expression

Résumé - Génétique moléculaire de Streptococcus thermophilus : de la transformation à l'expression des gènes. Streptococcus salivarius subsp thermophilus ( $\mathrm{S}$ thermophilus) est une bactérie lactique thermophile au métabolisme homofermentaire. Elle intervient dans la composition de nombreux levains utilisés en industrie agroalimentaire. Bien qu'ayant été utilisées depuis des centaines d'années, les recherches en matière de biologie moléculaire et de génétique sont relativement récentes. Nous reportons ici l'isolement et la caractérisation d'un plasmide cryptique de $3 \mathrm{~kb}$ ainsi que son utilisation pour l'élaboration d'un vecteur navette pouvant se répliquer chez $\mathrm{S}$ thermophilus comme chez E coli. En partant de cette base et en utilisant d'autres plasmides, la transformation de $\mathrm{S}$ thermophilus a été optimisée, puis utilisée pour l'intégration de plusieurs plasmides non réplicatifs. Des amplifications, suivies de réarrangements des séquences intégrées, ont été observées. Ces mécanismes furent alors utilisés pour introduire in vitro des délétions contrôlées dans un gène structural situé sur le chromosome de $\mathrm{S}$ thermophilus. De la même manière, un gène marqueur dépourvu de promoteur a été introduit dans l'opéron lactose, entre les séquences codant pour la perméase et la $\beta$-galactosidase. Nous reportons ici l'expression de ce gène au sein de l'opéron; il est régulé par le système de régulation propre à l'opéron. La sélection et le séquençage de promoteurs forts et faibles est sur le point de permettre l'analyse des séquences régulatrices.

Streptococcus salivarius subsp thermophilus / génétique moléculaire / transformation / intégration chromosomique / expression de gènes 


\section{INTRODUCTION}

Streptococcus salivarius subsp thermophilus ( $S$ thermophilus) is an important microorganism for the fermentation of food. It is predominantly used for the production of fermented milk products such as yoghurt and cheese. Only recently has progress been made in the genetics of this organism. Several gene transfer techniques such as conjugation (Gasson and Davies, 1980; Romero et al, 1987), transformation (Mercenier et al, 1988; Somkuti and Steinberg, 1988) and transfection (Mercenier et al, 1989) have been reported for this species. This enabled the examination and use of already existing bacterial plasmids as cloning vectors (Somkuti and Steinberg, 1988; Mercenier et al, 1989) as well as a beginning in designing new vector systems (Slos et al, 1991). Although very little is known about transcriptional and translational control regions in $S$ thermophilus (Mercenier and Lemoine, 1989; Mercenier, 1990), expression of some heterologous genes, delivered and maintained on plasmids, has been reported (Somkuti et al, 1991). However, expression levels are not predictable and often low or not detectable (Mercenier and Lemoine, 1989; Mercenier, 1990).

Plasmids are not a priori segregated in a stable way and may be lost under nonselective growth conditions. This may in particular be true for plasmid systems which are genetically engineered and carry heterologous DNA. Selection applied for ensuring plasmid maintenance in most cases make use of marker genes referring resistance to antibiotics. Although very convenient for laboratory experiments, such a selection system cannot be applied in food production. To date, a food grade gene transfer system for $S$ thermophilus has not been reported. It is in light of these interests that we started our own work on the molecular biology of $S$ thermophilus. In this arti- cle, we present an overview of some recent progress from our laboratory on plasmid development, transformation, genomic integration and gene expression.

\section{PLASMIDS}

$S$ thermophilus is a species which seems to be naturally poor in plasmids. However, several small cryptic plasmids were identified from different strains (reviewed by Mercenier; 1990). Six $S$ thermophilus production strains from our collection were analyzed for the presence of natural plasmids by agarose gel electrophoresis. Only one strain showed the presence of a 3-kb plasmid DNA, named PCRN201. A restriction map of the plasmid was determined (fig 1) and showed several unique restriction sites. In order to identify the region essential for replication in $S$ thermophilus, several different subclones of pCRN201 were constructed in E coli and tested for replication in $S$ thermophilus. The potential region of the replication origin is indicated in figure 1. Unique restriction sites not located within the origin of replication could now be used as convenient cloning sites. Suitable $E$ coli - S thermophilus shuttle vectors, eg

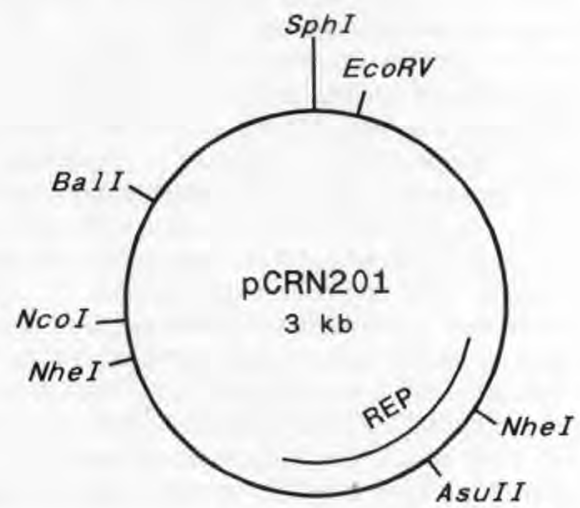

Fig 1. Restriction map of plasmid pCRN201. 
pDP160 which has pJDC9 (Chen and Morrison, 1988) inserted at the Sphl site of pCRN201, were constructed and are in use in our laboratory.

\section{TRANSFORMATION}

Plasmids used to transform $S$ thermophilus were pDP160, pVA838 (Macrina et al, 1982) and pNZ12 (Simons and de Vos, 1987). They all replicate in both $E$ coli and $S$ thermophilus, and their antibiotic resistance markers, either erythromycin or chloramphenicol, are functional in the 2 host systems for appropriate selection. As the transformation method we used electroporation. The protocols proposed by Somkuti and Steinberg (1988) and Mercenier (1990) gave insufficient transformation frequencies with our production strains. Hence, we optimized the conditions for one of our strains, ST11, by applying a mathematical iteration process of multifactorial experimental plans (Cochran and Cox, 1957). We now routinely obtain transformation frequencies of $10^{4}-$ $>10^{5}$ transformants per $\mu \mathrm{g}$ DNA, depending on the choice of plasmid and mode of selection (Marciset and Mollet, unpublished results). The frequencies are now suitable for direct cloning and genome integration experiments. It is worth mentioning that the individual methods for high rate transformation are very strain-specific and have to be optimized for each new specific strain. However, transformation frequencies are usually high enough to successfully transfer plasmids to different strains.

\section{GENOMIC INTEGRATION}

In order to investigate integration of DNA into the bacterial genome, we transformed ST11 with $E$ coli based plasmid DNA, which cannot autonomously replicate in $S$ thermophilus. The plasmids, derivatives of pUC19 (Yanisch-Perron et al, 1985) and pGEM5 (Promega, USA), carry the erythromycin resistance gene from pVA838 and contain DNA inserts of between 1.55$3.2 \mathrm{~kb}$, homologous to the lactose permease and $\beta$-galactosidase locus of the genome (Herman and McKay, 1986; Poolman et al, 1989; Schroeder et al, 1991). After transformation, erythromycinresistant colonies appeared on selective agar plates at a frequency of between 1$10^{2}$ transformants per $\mu \mathrm{g}$ DNA. Genomic DNA analysis, using Southern blot hybridization techniques, confirmed that the transformants had the $E$ coli plasmid integrated into the genome and maintained it by passive replication. All analyzed insertions, without exception, recombined into the genome at their homologous DNA stretch and formed classical cointegrates, whereby the homologous DNA region flank the integrated plasmid. Upon stringent selection on erythromycin, amplification of the cointegrates occurred, thus giving rise to an increased copy number of the integrated plasmid, ie the antibiotic resistance gene. A schematic representation of the recombination events is shown in figure 2.
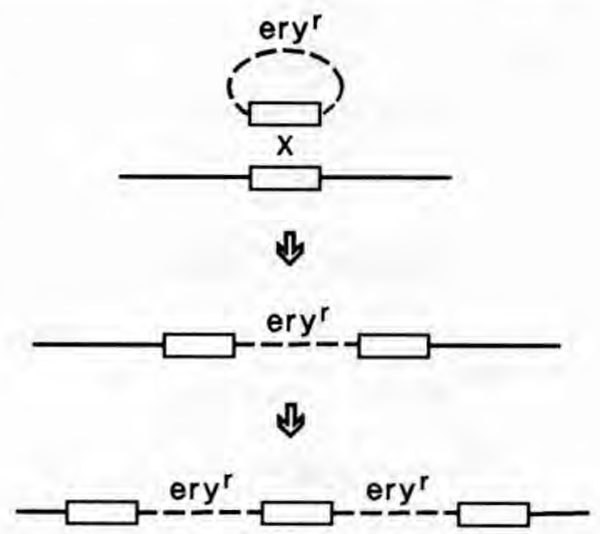

Fig 2. Plasmid integration and amplification. Boxes represent stretches of homologous DNA. Plasmid vector sequences with the erythromycin resistance gene $\left(e r y^{\prime}\right)$ are indicated as broken lines. 
The flanking repeats of the cointegrates were not only able to amplify the integrated plasmids, but also to resolve the cointegrates upon release of the selective pressure. This was shown by integrating plasmids containing in vitro generated deletions within the $\beta$-galactosidase gene. Appropriate resolution of the corresponding cointegrates resulted in a perfect replacement of the wild-type gene by its modified version (see fig 3 ). The modified strains were now again erythromycinsensitive. They grew as white colonies on appropriate X-gal plates and were unable to ferment lactose. Southern blot analysis verified the presence of the genetic modifications and the absence of plasmid DNA.

\section{INTEGRATIVE GENE EXPRESSION}

The method of genomic cointegrate formation and resolution gives us not only the possibility to delete or replace DNA sequences, but also to very specifically integrate heterologous genes. Therefore, it

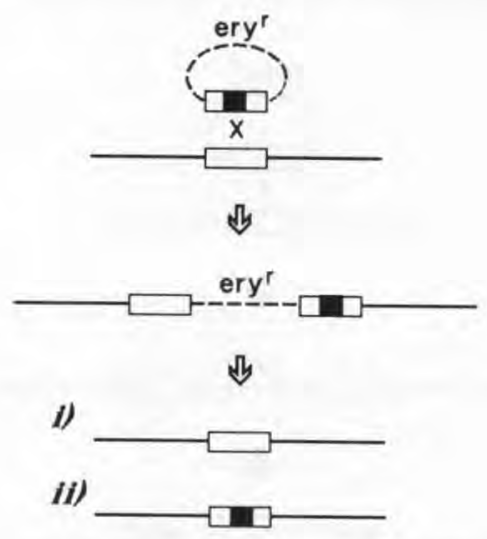

Fig 3. Gene replacement. Symbols are as in figure 2. A black box within the homologous DNA indicates the in vitro generated deletion. Resolution of the cointegrate results either in wild-type configuration (i) or gene-replacement (ii). should be possible to integrate a gene of interest into a vital operon of the $S$ thermophilus genome in such a way as to preserve the correct functioning, ie transcription and translation, of the operon and to have the heterologous gene as an integrative, functional part of the operon. The gene should be placed in front of an essential cistron of the operon. Thus, selective pressure on the essential gene during cell growth would ensure genetic maintenance and expression of the integrated gene. According to which operon is chosen as carrier system, different levels of expression and possibilities of regulation can be adopted.

In order to demonstrate the feasibility of such a procedure a marker gene, the promoter-less cat gene isolated from pNZ12, was inserted precisely between the lactose permease and $\beta$-galactosidase gene of an integration plasmid. The plasmid was then used to replace the original lactose operon of ST11 with the new construction by making use of the above-described 2-step recombination processes. Correct isolates were identified and named ST11-Cat. The new gene organization of the modified op-

\section{ST11:}

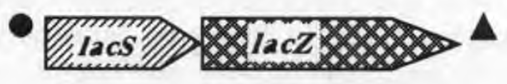

\section{ST11-Cat:}

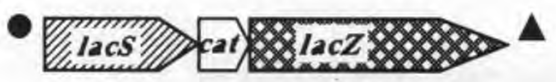

Fig 4. Lactose operon of ST11 and ST11-Cat. Lactose permease and $\beta$-galactosidase genes are marked with lacS and lacZ, respectively, the chloramphenicol acetyl transferase gene with cat. Promoter $(\bullet)$ and terminator $(\mathbf{\Delta})$ are indicated. 
eron (verified by Southern blot analysis) is shown in figure 4. Growth of ST11-Cat is now resistant to chloramphenicol: expression and regulation of the cat gene was shown to be parallel to that of the $B$ galactosidase gene, which is vital for growth of ST11-Cat on lactose, ie milk. Analysis of independent colonies after growth in milk for $>100$ generations indicated that the cat gene was durably maintained.

\section{GENE EXPRESSION}

The 2 modified ST11 strains produced from the integration techniques are now being used to study gene expression in this organism.

The ST11 strain with the integrated cat gene has been treated with mutagens and colonies selected which are capable of growth in the presence of increasing concentrations of chloramphenicol. Those mutants which also have a concomitant increase of B-galactosidase activity are analysed for mutations within the promoter region of the lactose operon (Constable and Mollet, unpublished results). Similarly, mutations are being analysed which cause a decrease in the expession of the 2 genes.

Using the $\beta$-galactosidase minus ST11 host strain, work is ongoing on the characterization of other important signal sequences involved in gene expression. Promoter probe vectors have been constructed which use the homogenic, promoter-less $\beta$-galactosidase gene as a marker. This has advantages over the more commonly used antibiotic resistance genes for promoter identification in that it is a homogenic gene, eliminating problems associated with codon usage and toxicity. Furthermore, its expression levels can be directly assayed by using chromogenic substrates.

\section{CONCLUSIONS}

In this article, we showed that the basic tools and techniques for applying molecular genetics in $S$ thermophilus have been developed to a great extent. Specifically, it is now possible to efficiently transform selected strains with well characterized plasmids, to integrate and amplify plasmids on the bacterial genome and to engineer, replace or introduce new genes directly on the genome.

The isolation and characterization of bona fide $S$ thermophilus plasmids gives us the possibility to develop them into easy, efficient food-grade transformation vectors. Studies to integrate a homogenic expression system onto such a plasmid for controlled gene expression are in progress in our laboratory.

As transposition in $S$ thermophilus has not yet been reported, cointegrative plasmid integration may serve as an alternative method for integrating DNA into the bacterial chromosome and disrupting genomic genes or gene structures. For these purposes, the homologous target sequences present on the integration plasmids need not a priori be identified. In fact, plasmids carrying genomic DNA from shotgun cloning can be used for quasi-random integration.

We have shown that genes can be integrated specifically into functional operons and, hence, be controllably expressed. This provides several important advantages over the more traditional plasmid transformation and expression systems: i) promoter and regulator regions do not have to be cloned and engineered; ii) the gene transfer system is absolutely food-grade; iii) integration of the gene is stable; and iv) selection for maintenance and expression of the gene is indirect, ie via selection for the downstream placed cistron within the operon. In particular, integration of a gene 
into the lactose operon in front of the Bgalactosidase gene ensures its expression and maintenance during growth of the strain in its natural habitat, milk.

Integrative expression of an antibiotic resistance marker gene, eg against chloramphenicol, under lactose operon regulation provides us with an ideal system to genetically investigate the involved control elements. In the same manner, analysis of the control region of other known genes can be achieved. Subsequent identification of sequences directing expression of the plasmid located $\beta$-galactosidase gene will complement the above-determined data.

\section{REFERENCES}

Chen JD, Morrison DA (1988) Construction and properties of a new insertion vector, pJDC9, that is protected by transcriptional terminators and useful for cloning of DNA from Streptococcus pneumoniae. Gene 64, 155-164

Cochran WG, Cox GM (1957) Experimental Designs. Wiley, New York

Gasson MJ, Davies FL (1980) Conjugal transfer of the drug resistance plasmid $\mathrm{pAM} \beta$ in the lactic streptococci. FEMS Microbiol Lett 7, 51-53

Herman RE, McKay LL (1986) Cloning and expression of the $\beta$-D-galactosidase gene from Streptococcus thermophilus in Escherichia coli. Appl Environ Microbiol 52, 45-50

Macrina FL, Tobian JA, Jones KR, Evans RP, Clewell DB (1982) A cloning vector able to replicate in Escherichia coli and Streptococcus sanguis. Gene 19, 345-353

Mercenier A (1990) Molecular genetics of Streptococcus thermophilus. FEMS Microbiol Rev 87, 61-78

Mercenier A, Lemoine $Y$ (1989) Genetics of Streptococcus thermophilus: a review. J Dairy Sci 72, 3444-3454
Mercenier A, Slos P, Faelen M, Lecocq JP (1988) Plasmid transduction in Streptococcus thermophilus. Mol Gen Genet 212, 386-389

Mercenier A, Robert C, Romero DA, Castellino I, Slos P, Lemoine $Y$ (1989) Development of an efficient spheroplast transformation procedure for $S$ thermophilus: the use of transfection to define a regeneration medium. Biochimie 70, 567-577

Poolman B, Royer TJ, Mainzer SE, Schmidt BF (1989) Lactose transport system of Streptococcus thermophilus: a hybrid protein with homology to the melibiose carrier and enzyme III of phosphoenolpyruvate-dependent phosphotransferase systems. J Bacteriol 171, 244-253

Romero DA, Slos P, Robert C, Castellino I, Mercenier A (1987) Conjugative mobilization as an alternative vector delivery system for lactic streptococci. Appl Environ Microbiol 53, 2405-2413

Schroeder CJ, Robert C, Lenzen G, McKay LL, Mercenier A (1991) Analysis of the lacZ sequences from two Streptococcus thermophilus strains: comparison with the Escherichia coli and Lactobacillus bulgaricus $\beta$ galactosidase sequences. J Gen Microbiol $137,369-380$

Simons G, de Vos WM (1987) Gene expression in lactic streptococci. Proc 4th Eur Congr Biotechnol vol 1, 458-460

Slos P, Bourquin JC, Lemoine Y, Mercenier A (1991) Isolation and characterization of chromosomal promoters of Streptococcus salivarius subsp thermophilus. Appl Environ Microbiol 57, 1333-1339

Somkuti GA, Steinberg DH (1988) Genetic transformation of Streptococcus thermophilus by electroporation. Biochimie 70, 579-585

Somkuti GA, Solaiman DKY, Johnson TL, Steinberg DH (1991) Transfer and expression of a Streptomyces cholesterol oxidase gene in Streptococcus thermophilus. Biotechnol Appl Biochem 13, 238-245

Yanisch-Perron C, Vieira J, Messing J (1985) Improved M13 phage cloning vectors and host strains: nucleotide sequences of the M13mp18 and pUC19 vectors. Gene 33, 103-119 